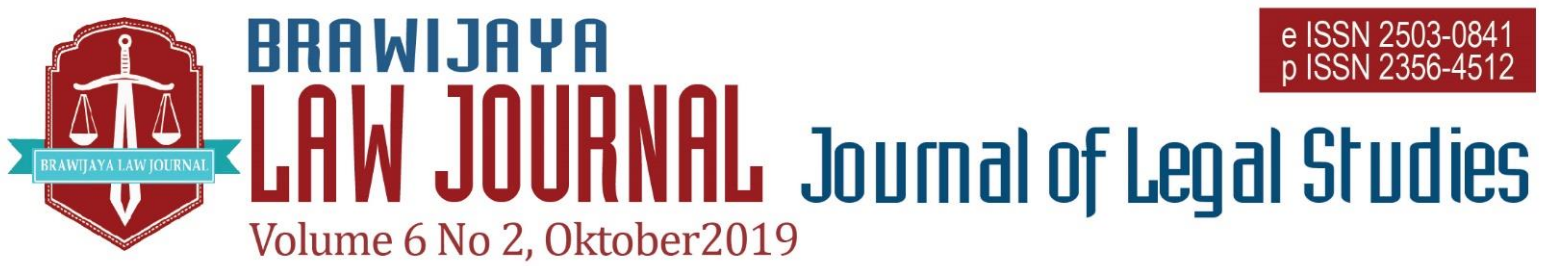

Nationally Accredited No. 30/E/KPT/2018 Dated 24th October 2018

This work is licensed under a Creative Commons Attribution-NonCommercial 4.0 International License

\title{
Criminal Law Enforcement of Indonesian Commerce Act Number 7 the Year 2014 for Corporation Perpetrators: Why It Will Be Difficult
}

\author{
Alfons Zakaria \\ Faculty of Law, Universitas Brawijaya \\ Email: al_zaka@yahoo.com
}

Submitted : 2019-02-18 | Accepted : 2019-09-25

\begin{abstract}
Indonesian laws have recognized the legal person as a subject of criminal law. It can be seen in all regulations enacted recently acknowledging that "any person" is a natural person (natuurlijk persoon) and legal person (rechtspersoon) who are liable for criminal punishments. Related to legal person or corporation, Indonesia, on the other hand, regulates corporate criminal responsibility differently in every single law. Some laws contain complete provisions, but others may fail to set the regulation properly. The Indonesian Commerce Act Number 7 the year 2014, for example, the legislators might miss drawing the provisions regulating corporate criminal responsibility. The Act recognizes corporations as a legal subject, but there is the absence of provisions related to when corporations shall be categorized committing a crime, which party shall be responsible when corporations shall be responsible, and what punishments shall be proper for corporations. Furthermore, it is commonly used, that if there is an absence of criminal law provisions in an act, the Criminal Code and Criminal Procedure Code will be the referral sources. In terms of corporate criminal responsibility regulation, however, both the Criminal Code and Criminal Procedure Code do not recognize the corporation as the subject of criminal law. Thus, the codes may not suitable as the referral sources for corporate crime law. Unfortunately, corporations violating the Act, then, will be difficult to be enforced in the judicial process. As a legal research paper, it will argue that the absence of the provision related to corporate criminal responsibility leads to the failure of law enforcement of corporation wrongdoings by presenting prospective consequences of the absence of such provisions.
\end{abstract}

Keywords: corporate crime; corporation; corporate criminal responsibility.

\section{INTRODUCTION}

Corporations are immensely powerful entities capable of both greatly increasing human welfare and harming it. It is, therefore, important that both corporations and the people who work on their behalf are appropriately regulated and controlled. ${ }^{1}$

1 James $\mathrm{M}$ Anderson and Ivan Waggoner, The Changing Role of Criminal Law in Controlling

Corporate Behavior (RAND Corporation, Santa Monica, Calif, 2014) ix. 
The Commerce Act Number 7 the Year 2014 is addressed to increase national economic growth, ensure smooth distribution and availability of basic needs goods and essential goods, improve consumer protection and improve the protection of natural resources. Accordingly, the Act regulates only activities committed by people who involve in the business area. The people are business players, exporters and importers. The Act acknowledges, in Article 1, that business players, exporters and importers are an individual or corporation (natuurlijk person or rechtspersoon). The Criminal Sanction Chapter of the Act regulates that wrongdoings are not committed by any person as other regulations, but only committed by business players, exporters, importers, producers and service providers. This means that criminal punishment regulated will be imposed on an individual or corporation who act as business players, exporters and importers. However, there is an absence of provisions related to corporate criminal responsibility. The Act does not regulate when business players, exporters and importers as a corporation can be considered committing wrongdoings, or what sanctions that appropriate for a legal person. Corporations must be regulated differently compared to a natural person. Identifying the elements needed to be regulated in corporate criminal responsibility is not separated from the form and nature of corporations.

One example of financial crime regulated in the Act, is prohibition of goods distribution using "pyramid scheme" 2 mentioned in Article 105: "business player who implements a pyramid scheme system in

2 Debra A Valentine, Pyramid Schemes defines pyramid schemes ".... promise consumers or investors large profits based primarily on recruiting others to join their program, not based on profits from any real investment or real sale of distributing goods referred to Article 9 shall be sentenced with maximum imprisonment of 10 years and /or fine of ten billion rupiahs". If corporations, therefore, distribute their products using pyramid scheme, what provisions that can be implemented to determine, such as, who should be responsible and what proper sanctions for corporations.

Moreover, about the principle of legality, legislators should formulate the acts referred to criminal offences clearly and in detail. This is called the principle of lex certa or bestimmtheitsgebot. Legislators should define clearly without vague (nullum crimen sine lege stricta), so there is no ambiguity regarding the formulation of a prohibited act and given sanction. Formulation of unclear or overly complicated will only bring legal uncertainty, and then it would lead to the failure of law enforcement.

\section{LEGAL MATERIALS AND METHODS}

This research is legal research using the statute approach. Legal materials used in this research are primary legal materials and secondary legal material, primary legal materials include Indonesian regulations on the subject matter particularly the Commerce Act Number 7 the year 2014, secondary materials include books, journal articles and other relevant sources.

This paper will initially describe the principle of legality as the fundamental principle of law enforcement. Then, it will identify kinds of crimes regulated in the Commerce Act Number 7 the year 2014. Then, it will analyze the provisions that 
should be regulated corporate criminal responsibility in the Commerce Act Number 7 the year 2014, by comparing with other provisions in other laws. Finally, it will indicate the prospective consequences of the absence of such provisions.

\section{RESULT AND DISCUSSION}

\section{Principle of Legality}

The principle of legality or nullum delictum nulla poena sine praevia lege poenali means no offence, no punishment without a pre-existing penal provision. This principle accentuates that penal law must be strictly construed ${ }^{3}$ and there must not exist retroactive effect, ${ }^{4}$ and forbids analogies ${ }^{5}$. The main goals of the principle are to protect individual human rights and to promote the purposes of criminalization. ${ }^{6}$

According to Sudarto, the principle of legality contains two things: ${ }^{7}$

a. A criminal offence must be formulated or stated in the law. About this there are two consequences, the first is that the act of someone who has not listed in the law as a crime, cannot be punished, so with this principle, unwritten law lacks the power to be applied. Whereas the second consequence is an assumption that the prohibition of the use of analogies to make an action become a criminal offence as defined in the law.

b. Regulation of this law must exist before the occurrence of the crime.

3 Jerome Hall, General Principles of Criminal Law Second Edition (the Lawbook Exchange Ltd, 2010) 28.

4 Cian C. Murphy, 'The Principle of Legality in Criminal Law Under the ECHR', (2010) 2 European Human Rights Law Review 193

5 Gerhard Werle and Florian Jeßberger, Principles of International Criminal Law (Third Edit, 2014) 113.
Consequently, the law must not be retroactive.

Meanwhile, according to Moeljatno, from the principle of legality formulation, it can be concluded that: ${ }^{8}$

a. There are no actions which prohibited and threatened with criminal penalties if it was previously not stated in the law.

b. To determine the existence of criminal acts must not use an analogy.

c. The rule of criminal law does not apply retroactively.

While according to Fajrimei, in the tradition of civil law systems, there are four aspects of the principle of legality which is applied strictly, namely: legislation (law), retroactive, lex certa, and analogy. Regarding these four aspects, according to Roelof H Haveman, "though it might be said that not every aspect is that strong on its own, the combination of the four aspects gives more true meaning to the principle of legality". ${ }^{9}$ Based on history and definition, it can be concluded that the principle requires:

a. Laws must be in written (lex scripta)

b. Laws must be formulated in detail (lex certa)

c. Laws must not be applied retroactively (non-retroactivity)

d. Laws must not have interpreted by analogy

About laws must be in writing form, the legislators should formulate the elements of criminal offences clearly and in detail. It's called the principle of lex certa or bestimmtheitsgebot. Legislators should

6 Kenneth S Gallant, The Principle of Legality in International and Comparative Criminal Law (Cambridge University Press, 2009) 19-20.

7 Sudarto, Hukum Pidana I (Semarang: Yayasan Sudarto, 1990) 22.

8 Moeljatno, Asas-Asas Hukum Pidana (Jakarta: Rineka Cipta, 2002) 25.

9 Fajrimei A Gofar, Asas Legalitas Dalam Rancangan KUHP 2005 (Jakarta: ELSAM, 2005) 6. 
define clearly without vague (nullum crimen sine lege stricta), so there is no ambiguity regarding the formulation of a prohibited act and given sanction. Formulation of unclear or overly complicated will only bring legal uncertainty and hinder the success of the prosecution because people are always going to be able to defend themselves that such provisions are not useful as a code of conduct.

In terms of corporate criminal responsibility, regulations must provide provisions explaining criteria or restrictions on when a corporation can be said commits a criminal act. It should be regulated to determine which party can consider for. The provisions that can be used as the criteria or guidelines for determining when a corporation has been said to commit criminal offence spread over several laws.

\section{Crimes in Commerce Act Number 7 the Year 2014 \\ Chapter XVIII regulates kind $\mathrm{s}$ of} illegal activities that will be punishable for criminal sanctions. There are 13 articles, from Article 104 to Article 116, showing 13 kinds of wrongdoings, as presented in Table Kinds of Wrongdoing.

Table Kinds of Wrongdoing

\begin{tabular}{|c|c|c|c|}
\hline Article & Subject & Wrongdoing & Sanction \\
\hline 104 & $\begin{array}{l}\text { business } \\
\text { player }\end{array}$ & $\begin{array}{l}\text { do not use or do not complete the } \\
\text { Indonesian language labels on goods } \\
\text { traded in the country referred to Article } \\
6 \text { paragraph (1) }\end{array}$ & $\begin{array}{l}\text { maximum imprisonment of } 5 \text { years } \\
\text { and /or fine of five billion rupiahs. }\end{array}$ \\
\hline 105 & $\begin{array}{l}\text { business } \\
\text { player }\end{array}$ & $\begin{array}{l}\text { implement a pyramid scheme system in } \\
\text { distributing goods referred to Article } 9\end{array}$ & $\begin{array}{l}\text { maximum imprisonment of } 10 \\
\text { years and /or fine of ten billion } \\
\text { rupiahs. }\end{array}$ \\
\hline 106 & $\begin{array}{l}\text { business } \\
\text { player }\end{array}$ & $\begin{array}{l}\text { do not have licenses in business } \\
\text { activities, issued by the Minister referred } \\
\text { to Article } 24 \text { paragraph (1) }\end{array}$ & $\begin{array}{l}\text { maximum imprisonment of } 4 \text { years } \\
\text { and /or fine of ten billion rupiahs. }\end{array}$ \\
\hline 107 & $\begin{array}{l}\text { business } \\
\text { player }\end{array}$ & $\begin{array}{l}\text { Store staple food and/or essential goods } \\
\text { in certain number and time, in the event } \\
\text { of scarcity of goods, price volatility, } \\
\text { and/or traffic barriers in trade referred to } \\
\text { Article } 29 \text { paragraph (1) }\end{array}$ & $\begin{array}{l}\text { maximum imprisonment of } 5 \text { years } \\
\text { and /or fine of fifty billion rupiahs. }\end{array}$ \\
\hline 108 & $\begin{array}{l}\text { business } \\
\text { player }\end{array}$ & $\begin{array}{l}\text { manipulate the data and/or information } \\
\text { regarding the supply of basic needs } \\
\text { goods and/or essential goods as referred } \\
\text { to Article } 30 \text { paragraph (2) }\end{array}$ & $\begin{array}{l}\text { maximum imprisonment of } 4 \text { years } \\
\text { and /or fine of ten billion rupiahs. }\end{array}$ \\
\hline 109 & $\begin{array}{l}\text { Producer } \\
\text { or } \\
\text { importer }\end{array}$ & $\begin{array}{l}\text { trade goods related to security, safety, } \\
\text { health, and the environment that is not } \\
\text { registered to the Minister referred to } \\
\text { Article } 32 \text { paragraph (1) letter a }\end{array}$ & $\begin{array}{l}\text { maximum imprisonment of } 1 \text { year } \\
\text { and /or fine of five billion rupiahs. }\end{array}$ \\
\hline 110 & $\begin{array}{l}\text { business } \\
\text { player }\end{array}$ & $\begin{array}{l}\text { trade goods and/or services defined as } \\
\text { goods and/or services that are prohibited } \\
\text { to be traded as referred to Article } 36\end{array}$ & $\begin{array}{l}\text { maximum imprisonment of } 5 \text { years } \\
\text { and /or fine of five billion rupiahs. }\end{array}$ \\
\hline 111 & importer & $\begin{array}{l}\text { import goods that are not in new } \\
\text { condition as referred to Article } 47 \\
\text { paragraph (1) }\end{array}$ & $\begin{array}{l}\text { maximum imprisonment of } 5 \text { years } \\
\text { and /or fine of five billion rupiahs. }\end{array}$ \\
\hline 112 & exporter & $\begin{array}{l}\text { export goods defined as prohibited goods } \\
\text { to be exported as referred to Article } 51 \\
\text { paragraph (1) }\end{array}$ & $\begin{array}{l}\text { maximum imprisonment of } 5 \text { years } \\
\text { and /or fine of five billion rupiahs. }\end{array}$ \\
\hline & importer & $\begin{array}{l}\text { import goods defined as prohibited } \\
\text { goods to be imported as referred to } \\
\text { Article } 51 \text { paragraph (2) }\end{array}$ & $\begin{array}{l}\text { maximum imprisonment of } 5 \text { years } \\
\text { and /or fine of five billion rupiahs. }\end{array}$ \\
\hline
\end{tabular}




\begin{tabular}{|c|c|c|c|}
\hline Article & Subject & Wrongdoing & Sanction \\
\hline 113 & $\begin{array}{l}\text { business } \\
\text { player }\end{array}$ & $\begin{array}{l}\text { trade, in domestic, goods that do not } \\
\text { meet with SNI or technical requirements } \\
\text { that obligated enforced, as referred to } \\
\text { Article } 57 \text { paragraph (2) }\end{array}$ & $\begin{array}{l}\text { maximum imprisonment of } 5 \text { years } \\
\text { and /or fine of five billion rupiahs. }\end{array}$ \\
\hline 114 & $\begin{array}{l}\text { Service } \\
\text { provider }\end{array}$ & $\begin{array}{l}\text { trade, in domestic services that do not } \\
\text { meet with SNI, technical or qualification } \\
\text { requirements that obligated enforced, as } \\
\text { referred to Article } 60 \text { paragraph (1) }\end{array}$ & $\begin{array}{l}\text { maximum imprisonment of } 5 \text { years } \\
\text { and /or fine of five billion rupiahs. }\end{array}$ \\
\hline 115 & $\begin{array}{l}\text { business } \\
\text { player }\end{array}$ & $\begin{array}{l}\text { trade goods and /or services by using an } \\
\text { electronic system that is incompatible } \\
\text { with the data and/or information referred } \\
\text { to in Article } 65 \text { paragraph (2) }\end{array}$ & $\begin{array}{l}\text { maximum imprisonment of } 12 \\
\text { years and /or fine of twelve billion } \\
\text { rupiahs. }\end{array}$ \\
\hline 116 & $\begin{array}{l}\text { business } \\
\text { player }\end{array}$ & $\begin{array}{l}\text { organize trade fairs engages the learner } \\
\text { and/or products are promoted from } \\
\text { abroad which do not have permission } \\
\text { from the Minister referred to Article } 77 \\
\text { paragraph (2) }\end{array}$ & $\begin{array}{l}\text { maximum imprisonment of } 3 \text { years } \\
\text { and /or fine of five billion rupiahs. }\end{array}$ \\
\hline
\end{tabular}

There are two essential points from the table that must have taken about corporate regulations. First, the subjects of wrongdoing are only business players, exporters, importers, producers and service providers. Article 1 of the Act defines that business players, exporters and importers are an individual or corporation, either in the form of a legal entity or not. This means that corporations acting as business players, exporters and importers, are the subject of the Act. They can have charged on the punishments according to the articles. Second, the punishments, then, namely imprisonment and fine, are applied to business players, exporters, importers, producers and service providers who commit the wrongdoings, either an individual or corporation. The main question is whether corporations are possible to be sentenced to imprisonment. The answer of course not, as legal person shall be punished by fine only. The other questions then, what happen if the corporation will not be able to pay the fine.

To answer the question, Article 30 of the Indonesian Criminal Code (KUHP)

10 Dwidja Priyatno and Kristian, Kebijakan Formulasi Sistem Pertanggungjawaban Pidana Korporasi (Jakarta: Sinar Grafika, 2017) 29. explains that if the fine is not have paid, the penalty will have substituted by light imprisonment maximum of six months. The question again, is a legal person possible to be sentenced imprisonment? Accordingly, the punishments provided, imprisonment and fine, for a corporation or legal person committing wrongdoing, seem difficult to be enforced. This situation exists in some Indonesian laws. Thus, they seem to regulate corporate criminal responsibility inconsistently among regulations. ${ }^{10}$ The regulations are such as the Law Number 11 of 2008 on Electronic information and transactions, the Law Number 44 of 2008 on Pornography and the Law Number 18 of 2012 on Food.

\section{Absence of the Provisions}

Identifying the things needed to have regulated in a corporate criminal liability is not separated from the form and nature of the corporation. KUHP, on the other hand, only regulates person and does not recognise corporations as legal subjects. ${ }^{11}$ Accordingly, 
corporations shall be accurate regulated. ${ }^{12} \mathrm{At}$ least there are four things that needed to be regulated precisely regarding corporate criminal liability according to Barda Nawawi Arief, which are (1) when corporations shall be categorized committing crime; (2) which party shall be responsible; (3) when corporations shall be responsible; and (4) what punishments shall be proper for corporations. $^{13}$

The Commerce Act Number 7 the Year 2014 seems to fail to regulate such elements. Thus criminal law enforcement for corporations wrongdoers will not be useful. The following will have described on the need for those four things to be arranged particularly in a regulation.

\section{a. When Corporations shall be Categorized} Committing Crime

The Commerce Act Number 7 the Year 2014 acknowledges, in Article 1, that business players, exporters and importers are an individual or corporation (natuurlijk person or rechtspersoon). However, the problem is when is a crime can be said to be committed by a corporation. This is because the corporation can only run by people.

Muladi and Diah Sulityani maintain that there are five requirements related to the perpetrators of the corporation, namely (1) Is there any act by a person working in the corporation? (2) Is the action related to the business of the corporation? (3) Does the performance serve the corporation? (4) Is the

12 Henry Donald Lbn Toruan, 'Pertanggungjawaban Pidana Korupsi Korporasi' (2014) 3(3) Rechtsvinding 406.

13 Barda Nawawi Arief, Masalah Penegakan Hukum Dan Kebijakan Hukum Pidana Dalam Penanggulangan Kejahatan (Jakarta: Kencana Prenada Media Group, 2007) 151.

14 Muladi and Diah Sulityani, Pertanggungjawaban Pidana Korporasi (Bandung: Alumni, 2015) 41.

15 Council of Europe Criminal Law Convention on Corruption corporation able to decide the deed should be committed or not? (5) Is the act usually accepted by the corporation? ${ }^{14}$

Furthermore, Article 18 of Council of Europe Criminal Law Convention on Corruption emphasizes that: "legal persons can be held liable for the criminal offences" committed for their benefit by any natural person, acting either individually or as part of an organ of the legal person, who has a leading position within the legal person, based on a power of representation of the legal person; or an authority to make decisions on behalf of the legal person; or an authority to exercise control within the legal person. ${ }^{15}$

The principle suitable to determine whether a corporation has committed a crime is the principle of strict liability. The principle is an expression that shows a criminal act does not require fault to one or more elements of the actus reus. ${ }^{16}$ The reason on the premise that states there is no fault at all in strict liability is that someone is not necessarily convicted even though he already committed action prohibited by law.

In contrast, strict liability that must be made stricter requirements (absolute liability) is that in the case of strict liability a person who has committed the forbidden act (actus reus) as defined in the law, may be convicted without the need to question whether he has a fault (mens rea) or not. ${ }^{17}$ The implementation of this principle will remove the requirement to prove a guilty mind by

<https://rm.coe.int/CoERMPublicCommonSearch Services/DisplayDCTMContent?documentId=090 000168007f3f5>.

16 Mahrus Ali, Kejahatan Korporasi (Yogyakarta: Arti Bumi Intaran, 2008) 53.

17 Hulsman in Hamzah Hatrik, Asas Pertanggungjawaban Korporasi Dalam Hukum Pidana Indonesia (Strict Liability and Vicarious Liability) (Jakarta: Raja Grafindo Persada, 1996) 110. 
public prosecutors, for example, intent, knowledge or recklessness 18 or psychological matter ${ }^{19}$.

Based on the provisions above, it can conclud that the Commerce Act Number 7 the Year 2014 should contain provisions regulating when a criminal offence have indicated committed by a corporation if the criminal offence:

(1) performed by a person alone or on the order of the person controlling the corporation, the authorized personnel make decisions on behalf of the corporation or representing the corporation to perform a legal act or has the authority to control and/ or supervise the corporation;

(2) performed in its business scope as specified in the articles of association or other provision applicable to the corporation concerned;

(3) performed to meet the intent and purpose of the corporation;

(4) performed in by the duties and functions of the perpetrator or any of the command;

(5) performed to provide benefits to the corporation; and

(6) performed either alone or together.

b. What Party shall be Responsible

The Commerce Act Number 7 the Year 2014 acknowledges that business players, exporters and importers are an individual or corporation. The Act, however, does not regulate who should be responsible in corporations for wrongdoing committed by corporations. In determining who should be responsible, there are three models of

18 Corporations and Financial Services Division of The Australian Treasury, Review of Sanctions in Corporate Law <http://archive.treasury.gov.au/contentitem.asp?C ontentID=1182>.

19 Ridho Kurniawan and Siti Nurul Intan Sari, 'Pertanggungjawaban Pidana Korporasi corporate responsibility, which is known, namely (1) The board of corporation as the maker who responsible; (2) Corporation as the maker and administrator who responsible; (3) Corporation as the maker who is responsible as well. ${ }^{20}$

In the model of corporate responsibility, there is a change that a corporation can be accounted for as a maker besides as a human being (naturlijk persoon). Thus, rejection of corporate criminal prosecution has been amended to accept the concept of the functional offender (functioneel daderschap). 21 It means that this responsibility system is the beginning of the direct responsibility of the corporation.

This model is the beginning of the direct responsibility of the corporation as well as the maker who has the responsibility. The motivation is to pay attention to the development of the corporation itself, which is for some particular offences, the enactment of the board of the corporation as the one who can be punished is not enough. In economic offences, it is not impossible that the fine imposed as a penalty to the board compared to the benefits that have been received by the corporation to perform the act or losses incurred in the community, or suffered by rivals, gains or losses, is greater than the fine imposed as punishment. The criminal punishment for the board of the corporation does not provide sufficient assurance that the corporation will not commit the offence forbidden by the law again. It turns out that it is not enough to hold the repression of offences committed by or with a corporation. Therefore it is also necessary to give a

Berdasarkan Asas Strict Liability' (2014) 1(2) Jurnal Yuris 162.

20 Setiyono, Kejahatan Korporasi (Malang: Bayumedia Publishing, 2009) 12-14.

21 Ibid 16. 
criminal punishment to the corporation, and the board of the corporation or just the board. ${ }^{22}$

Moreover, there are some things that can be used as a justification that the corporation as a maker and at the same time the one who responsible, firstly, because in many criminal acts of economic and fiscal, corporate profits or losses suffered by the community can be significant, so it will not maybe be balanced when the criminal is only imposed on the board alone. Second, criminalizing the board only, or there is no guarantee that the corporation will not repeat criminal offences. With corporate criminalized by type and weight according to the nature of the corporation, the corporation is expected to be able to comply with the relevant regulations. ${ }^{23}$

The more appropriate provision is that it allows the board or corporation itself to be accounted for, either individually or jointly, if the corporation has committed the crime. A closely related legal concept to corporate criminal liability is vicarious criminal liability, where the liability of superiors for the actions of their employees. ${ }^{24}$ Andrew Weissmann and David Newman state that "a corporation is liable for the actions of its agents whenever such agents act within the scope of their employment and at least in part to benefit the corporation. ${ }^{25}$ Moreover, James M. Anderson and Ivan Waggoner believe that "Whether an activity falls within the individual's scope of authority is determined by whether the individual engages in activities “on the corporation's behalf in performance of [his or her] general line of work. ... [T]hose acts must be motivated, at

22 Dwidja Priyatno, Kebijakan Legislasi Tentang Sistem Pertanggungjawaban Pidana Korporasi Di Indonesia (Bandung: CV Utomo, 2004) 57.

23 Setiyono, above n 19, 15.

24 Anderson and Waggoner, above n 1, 26. least in part, by an intent to benefit the corporation." 26

To reconcile with the absence of corporate criminal responsibility in Indonesian regulations, the Indonesian Supreme Court enacted regulation number 13 of 2016 concerning the Procedures in Handling Corporate Crime. The regulation mentions that in imposing criminal penalties for corporations, Judges may consider corporation's fault based on whether (1) corporations obtain profits or benefits from the crime or the crime is committed for the benefit of the corporation; (2) corporations let crime occurs; or (3) corporations do not take the necessary steps to take precautions, prevent greater impacts and ensure compliance with applicable legal provisions to avoid criminal acts.

c. When Corporations shall be Responsible

The Commerce Act Number 7 the Year 2014 also fails to provide provisions regulating when corporations shall be taken responsible for their offensive act. The criteria of when a corporation holds a criminal responsibility is not have separated from the criteria of when a corporation has committed a crime. If the criterion of when a corporation has committed a crime fulfilled, then the responsibility can be charged to the corporation. Later, the provision that needs to be regulated is which party has to represent the corporation in a legal process that must be followed? Some laws have given examples of who should represent the corporation in legal proceedings.

The basic reasons that must have used in determining when corporation should be

25 Andrew Weissmann and David Newman, 'Rethinking Criminal Corporate Liability' (2007) 82 Indiana Law Journal 422.

26 Anderson and Waggoner, above n 1, 5. 
responsible according to Clinard and Yeager are (1) the degree of loss to the public; (2) the level of complicity by high corporate managers; (3) the duration of the violation; (4) the frequency of the violation by the corporations; (5) evidence on intent to violate; (6) evidence of extortion, as bribery cases; (7) the degree of notoriety engendered by the media; (8) precedent in law; (9) the history of serious violation by the corporation; (10) deterrence potential; (11) the degree of corporation evinced by the corporation. ${ }^{27}$

d. What Punishments shall have proper for Corporations

There is an absence of provisions regulating criminal sanctions for corporations in the Commerce Act Number 7 the Year 2014. Regulating criminal sanctions for the corporation must consider the nature of the corporation which is different from a natural person. A responsibility of corporation and people is comparable, but there are exceptions. At least two things can be used as an exception to corporate responsibility, which are:

1) In those cases which by its nature cannot be done by the corporation, such as rape, and

2) In the case that the only crime which may be determined cannot have subjected to the corporation, such as imprisonment and death penalty. ${ }^{28}$

27 Muladi and Sulityani, above n 13, 62.

28 Setiyono, above n 19, 109.

29 Ibid 119.

30 Corporations and Financial Services Division of The Australian Treasury, Review of Sanctions in Corporate Law, above n 17, 18.

31 William Robert Thomas, How and Why Should the Criminal Law Punish Corporations? (Dissertation, the University of Michigan, 2015) 174 <https://deepblue.lib.umich.edu/bitstream/handle/
While the additional sanctions for corporations, besides criminal sanctions, are: ${ }^{29}$

a). The closure of all or part of the corporation in a specific time or permanently;

b). Revocation of the facilities provided by the government to the corporation concerned within a spesific time or forever;

c). Placing the corporation under guardianship within a specified time.

Regulating civil sanctions also provide advantages for law enforcement such as minimize overall enforcement costs. ${ }^{30}$ The proper punishment for corporations that eligible for criminal liability is only a criminal penalty. ${ }^{31}$ Almost all regulations, in Indonesia, indicate that punishment for corporations is fine. However, the regulations do not manage provisions related to substitute of fine. ${ }^{32}$ The problem then is if a punished corporation is not able to pay the fine, it shall be punished with light imprisonment as stated in article 30 of the Indonesian Criminal Code. Light imprisonment seems impossible for a corporation.

Sjahdeini also believes that only criminal fine is possible to be imposed for the corporation. ${ }^{33}$ Usually, punishments have regulated in the cumulative and alternative formulation. The punishment that shall be imposed for a corporation is punishment formulated in alternatively, such as

2027.42/113460/wrtrw_1.pdf?sequence=1\&isAll owed $=\mathrm{y},>$.

32 Andrianto, Pemikiran Dan Teknik Pembuatan Putusan Pemidanaan Terhadap Korporasi (Bandung: Mandar Maju, 2016) 5; Dwidja Priyatna, Sistem Pertanggungjawaban Korporasi Dalam Kebijakan Legislasi (Depok: Kencana, 2017) 185.

33 Sutan Remy Sjahdeini, Ajaran Pemidanaan: Tindak Pidana Korporasi \& Seluk Beluknya (Depok : Kencana, 2017) 268. 
imprisonment or fine. Other sanctions that can have given to the corporations, such as (1) financial sanctions; (2) appropriation of profits derived from the crime; (3) revocation of business license; (4) dissolution of the corporation; (5) mandatory management oversight; (6) community service order. ${ }^{34}$

\section{Consequences}

Obstacles in law enforcement come possibly from the law itself, namely (1) The fundamental principles are not complied by legislations; (2) There is the absence of implementing regulations needed for applying the legislation; (3) The ambiguity of the words in the legislation confused in the interpretation and application. ${ }^{35}$

Similarly, the absence of provision regulating criminal responsibility of corporations in the Commerce Act Number 7 the year 2014, will lead to unexpected consequences that direct to the inability of law enforcers to tackle corporates violating the Act. There are at least four consequences that may occur because of the absence of the provisions.

First, investigators and public attorneys will be lost to determine whether a corporation has conducted wrongdoing. They usually work under particular regulations as their formal guidance. Investigators and public attorneys might not be able to decide whether an offence performed by an individual or corporation, because there is no provision when wrongdoing is committed by a corporation. The error in indicating who subjects an offence in the indictment will lead to the decision of acquittal.

34 Muladi and Sulityani, above n 13, 69-70.

35 Soerjono Soekanto, Faktor-Faktor Yang Mempengaruhi Penegakan Hukum (Jakarta : Raja Grafindo Persada, 2012) 7.

36 Setiawan Noerdajasakti, Ismail Navianto and Alfons Zakaria, Kendala Penegekan Hukum
Second, the investigator and a public attorney will be puzzled to identify which part of the corporation shall bear responsibility. Although Investigators and public attorneys are successful to determine that a corporation has conducted crime, they are still difficult to identify which part of the corporation shall be responsible and who can perform in corporation's behalf. The error in indicating whom subjects of an offence in the indictment, awill lead to the decision of acquittal. $^{36}$

Third, judges do not have guidance to sentence appropriate sanction for accused corporations. A natural person (natuurlijk persoon) differs from a legal person (rechtspersoon).

Determining proper punishments for a corporation is not separated from the form and nature of corporations. A Legal person must not be able to be punished by the death penalty or imprisonment. Moreover, in the Indonesian criminal law system, judges require formal guidance in the form of regulations to sentence the accused. They are not allowed to sentence beyond what laws have formulated. They, therefore, will not be able to sentence appropriate punishment for corporations, such as freezing part or all activities of the corporation, revocation of business license, expropriation of assets of the corporation to the state and payment of compensation. Last but not least, these consequences will direct to the absence of a corporation that may be able to be punished under the Act. 


\section{CONCLUSION AND SUGGESTION}

Based on the discussions above, it can conclude that the Commerce Act Number 7 the year 2014 miss regulating the corporate criminal responsibility in its provisions. The provisions that must have legalized are related to when corporations shall be categorized committing a crime, which party shall be responsible when corporations shall be responsible, and what punishments shall be proper for corporations.

This kind of provisions is the mandate of the principle of legality as the fundamental principle for insurance the primacy of law in all criminal proceedings. This condition may lead to the inability of investigators and public attorneys to determine whether a corporation has conducted wrongdoing and then which part of the corporation shall bear responsibility.

This condition also leads to an inability for the sentencing appropriate punishment for corporations. Thus, legislators must revise the Commerce Act Number 7 the year 2014 and insert the provisions related the corporate criminal responsibility, to ensure that criminal law enforcement can be imposed for corporation wrongdoers.

\section{REFERENCES}

\section{Books}

Ali, Mahrus, Kejahatan Korporasi (Yogyakarta : Arti Bumi Intaran, 2008) Anderson, James $\mathrm{M}$ and Ivan Waggoner, The Changing Role of Criminal Law in Controlling Corporate Behavior (RAND Corporation, Santa Monica, Calif, 2014)

Andrianto, Pemikiran Dan Teknik Pembuatan Putusan Pemidanaan Terhadap Korporasi (Bandung: Mandar Maju, 2016)
Arief, Barda Nawawi, Masalah Penegakan Hukum Dan Kebijakan Hukum Pidana Dalam Penanggulangan Kejahatan (Jakarta: Kencana Prenada Media Group, 2007)

Gallant, Kenneth S, The Principle of Legality in International and Comparative Criminal Law (Cambridge University Press, 2009)

Gofar, Fajrimei A, Asas Legalitas Dalam Rancangan KUHP 2005 (Jakarta: ELSAM, 2005)

Hall, Jerome, General Principles of Criminal Law Second Edition (the Lawbook Exchange Ltd, 2010)

Hatrik, Hamzah, Asas Pertanggungjawaban Korporasi Dalam Hukum Pidana Indonesia (Strict Liability and Vicarious Liability) (Jakarta: Raja Grafindo Persada, 1996)

Moeljatno, Asas-Asas Hukum Pidana

(Jakarta: Rineka Cipta, 2002)

Muladi and Diah Sulityani, Pertanggungjawaban Pidana

Korporasi (Bandung: Alumni, 2015)

Priyatna, Dwidja, Sistem

Pertanggungjawaban Korporasi

Dalam Kebijakan Legislasi (Depok: Kencana, 2017)

Priyatno, Dwidja, Kebijakan Legislasi Tentang Sistem Pertanggungjawaban Pidana Korporasi Di Indonesia (Bandung : CV Utomo, 2004)

Priyatno, Dwidja and Kristian, Kebijakan Formulasi Sistem

Pertanggungjawaban Pidana

Korporasi (Jakarta: Sinar Grafika, 2017)

Setiyono, Kejahatan Korporasi (Malang:

Bayumedia Publishing, 2009)

Sjahdeini, Sutan Remy, Ajaran Pemidanaan:

Tindak Pidana Korporasi \& Seluk Beluknya (Depok : Kencana, 2017)

Soekanto, Soerjono, Faktor-Faktor Yang 
Mempengaruhi Penegakan Hukum

(Jakarta : Raja Grafindo Persada, 2012)

Sudarto, Hukum Pidana I (Semarang:

Yayasan Sudarto, 1990)

Werle, Gerhard and Florian Jeßberger, Principles of International Criminal Law (Third Edit, 2014)

\section{Journal Articles}

Cian C. Murphy, 'The Principle of Legality in Criminal Law Under the ECHR', (2010) 2 European Human Rights Law Review

Kurniawan, Ridho and Siti Nurul Intan Sari, 'Pertanggungjawaban Pidana Korporasi Berdasarkan Asas Strict Liability' (2014) 1(2) Jurnal Yuris

Padil, 'Karakteristik Pertanggungjawaban Pidana Korporasi Dalam Tindak Pidana Korupsi' (2016) 4(1) Jurnal IUS

Toruan, Henry Donald Lbn, 'Pertanggungjawaban Pidana Korupsi Korporasi' (2014) 3(3) Rechtsvinding

Weissmann, Andrew and David Newman, 'Rethinking Criminal Corporate Liability' (2007) 82 Indiana Law Journal

\section{Research Report}

Noerdajasakti, Setiawan, Ismail Navianto and Alfons Zakaria, Kendala
Penegekan Hukum Kejahatan Korpoasi Terkait Inkonsistensi Pengaturan Pertanggungjawaban Pidana Korporasi Dalam PerundangUndangan Di Indonesia, Studi Di Jawa Timur (Faculty of Law Brawijaya University, 2015)

\section{Internet Sources}

Corporations and Financial Services Division of The Australian Treasury, Review of Sanctions in Corporate Law $<$ http://archive.treasury.gov.au/content item.asp?ContentID=1182>

Council of Europe Criminal Law Convention on Corruption <https://rm.coe.int/CoERMPublicCom monSearchServices/DisplayDCTMCo ntent?documentId=090000168007f3f5 $>$

Thomas, William Robert, How and Why Should the Criminal Law Punish Corporations? (Dissertation, the University of Michigan, 2015) $<$ https://deepblue.lib.umich.edu/bitstre am/handle/2027.42/113460/wrtrw_1.p $\mathrm{df}$ ?sequence $=1 \&$ isAllowed $=\mathrm{y},>$

Valentine, Debra A, Pyramid Schemes $<$ https://www.ftc.gov/publicstatements/1998/05/pyramidschemes> 